
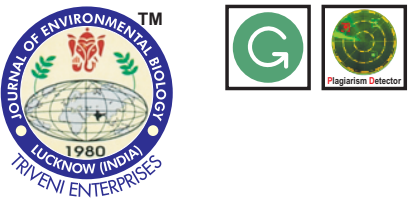

DOI : http://doi.org/10.22438/jeb/38/5/MS-235

\title{
Effect of Lactobacillus rhamnosus cells against specific and native fish spoilage bacteria and their spoilage indices on Asian seabass fish chunks
}

\section{Authors Info}

S. Kannappan ${ }^{1 *}$, K. Sivakumar ${ }^{2}$ and S. Sivagnanam ${ }^{1}$

${ }^{1}$ Nutrition, Genetics and Biotechnology Division, Central Institute of Brackishwater Aquaculture, Chennai - 600028 , India

${ }^{2}$ ICAR - Krishi Vigyan Kendra, Tamil Nadu Veterinary and Animal Sciences University, Kattupakkam 603203 , India

*Corresponding Author Email : sudalikanna@gmail.com

Key words

Antagonism,

Fish-borne bacteria,

Lb. rhamnosus,

Seabass fish,

Spoilage bacteria

\section{Publication Info}

Paper received : 31.12 .2015

Revised received : 17.07 .2016

Re-revised received : 10.10 .2016

Accepted : 24.12 .2016

\section{Abstract}

Aim : The present study aimed at evaluating probiotic bacterial cells, Lb. rhamnosus by coating on seabass fish meat chunks against its spoilage indices, native and specific fish spoilage bacteria.

Methodology : Seabass fish fillets were cut into chunks, washed and taken into petri plates. Scores were made using sterile blade. $L b$. rhamnosus cells were coated on the chunks using micro pipette and tested for antagonism against fish-borne specific spoilage bacteria such as Shewanella putrefaciens and Pseudomonas fluorescens through "Deferred antagonism assay". Spent culture of Lb. rhamnosus was assayed for antagonism through "Agar-well diffusion assay". The changes were estimated for two days following "Conway micro diffusion" method.

Results : Lb. rhamnosus cells when co-cultured with $P$. fluorescens were inhibited on the second day by 1.0 log difference as compared with control. The spent culture of $L b$.rhamnosus, after treating at $121^{\circ} \mathrm{C}$ for $10 \mathrm{~min}$ showed inhibition against $P$. fluorescens. But the spent culture after treatment at $100^{\circ} \mathrm{C}$ showed difference of inhibitory zone at $5.0 \mathrm{~mm}$ against $S$. putrefaciens. $L b$. rhamnosus cells when coated on seabass fish meat chunks, the native proteolytic bacteria was inhibited by $L b$. rhamnosus on $3^{\text {rd }}$ day by 1.3 log difference as compared to control. $L b$. rhamnosus cell coat, reduced fish spoilage indices such as TrimethylamineNitrogen (TMA-N) and Total volatile bases- Nitrogen (TVB-N) by $80 \mathrm{mg} \%$ difference.

Interpretation : The study concluded that coating of probiotic $L b$. rhamnosus cells on fish meat would contribute antagonism and regulate the growth of specific and native spoilage bacteria with spoilage indices.

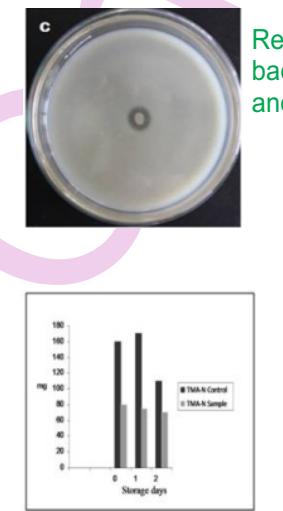

Spoilage indices such as Trimethylamine-Nitrogen and Total volatile bases- Nitrogen
Reduced, specific spoilage bacteria like S. putrefaciens and $P$. fluorescens
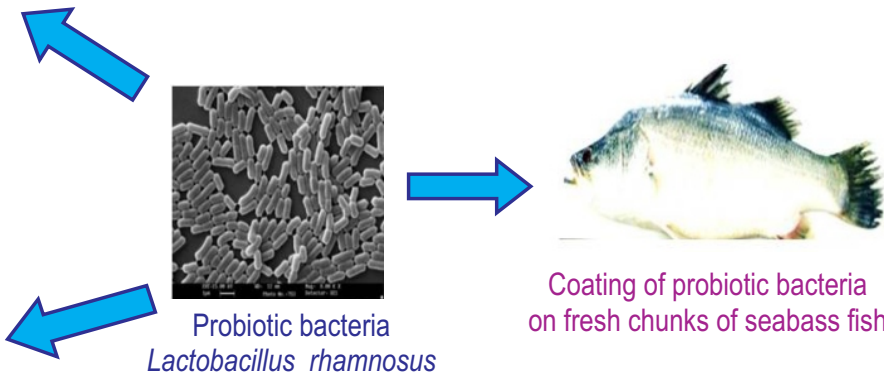

Coating of probiotic bacteria on fresh chunks of seabass fish
Antagonism of $L b$. rhamnosus against S. putrefaciens and $P$. fluorescens in Asian seabass fish meat chunks 


\section{Introduction}

Fish is a highly perishable food which spoils faster than any other meat owing to the presence of unsaturated fatty acids in it, therefore fish has to be preserved rapidly soon after harvest. The shelf life of fish is always assessed based on the freshness and spoilage level (Ghaly et al., 2010). Shewanella putrefaciens and $P$ seudomonas fluorescens are the foremost specific spoilage bacteria found among the marine fish (Aberoumand, 2010). $P$. fluorescens is morphologically a Gram-negative rod that causes hemorrhage in fish skin, fins, oral cavity and muscles (Tsai et al., 2008). Specific spoilage level is responsible for the conversion of Trimethylamine oxide to trimethylamine in fish. Under specific spoilage bacteria, S. putrefaciens causes common clinical manifestations such as otitis, soft tissue infection, bacteraemia and infection among human beings. S. putrefaciens also produce off-flavour in fish at high $\left(10^{8} \mathrm{cfu}^{-1}\right)$ cell density (Tsai et al., 2008).

Lactic acid bacteria has long been recognized as biopreservative bacteria due to their inhibition potential against bacterial pathogens by producing organic acids and bacteriocin like inhibitory substances, etc (Zaheer et al., 2010). Under Lactic acid bacteria the use of probiotic bacteria is gaining recognition to control aquatic bacterial pathogens (Lara-Flores, 2011) in aquaculture. Probiotics bacteria such as ammonia oxidizing and nitrite oxidizing bacteria have been reported to be effective in monitoring microbiological and environmental parameters in Litopenaeus vannameigrow-out practices (Patil etal., 2016).

Supplementation of Lactic acid bacteria in broiler as probiotic bacteria improves the meat quality (Kabir, 2009). Antimicrobial activity of Lactobacillus rhamnosus has been well documented for controlling food spoilage bacteria (Magdalena et al.,2009) has been used to control trimethylamine nitrogen and spoilage indices in fresh Indian Mackerel fish (Kannappan and Manja, 2011). The efficacy of lactic acid bacteria in controlling human pathogenic bacteria and fish-borne spoilage microbiota were studied on fresh mackerel fish chunks (Kannappan and Manja, 2012). Chemicals cannot be used as fish preservative agent because of the disagreeable contamination caused to the contemporary consumers. Further, chemical preservatives are not much encouraging in combating fish-borne spoilage bacteria. Thus, fish preservation using Lactic acid bacteria as biopreservative agent would increase the shelf life. Lb. rhamnosus GG, human gut-borne lactic bacteria, has been well proved as antagonistic agent against pathogenic and food spoilage microbes (Sarika et al., 2010). Lb. rhamnosus has been used as feed supplement cum probiotic bacteria during the grow-out practices of rainbow trout fish (Balcazer et al., 2006). Lb. rhamnosus has different immune-stimulative effects with reduced intestinal damage when challenged against pathogenic Aeromonas bacteria (Ngamkala et al., 2010). In India, the application of Lactic acid bacteria is well propagated in milk based products. But, yet to disseminate in fish based products. $L b$. rhamnosus, probiotic bacteria has specially been selected for humans since it has been exposed to be harmless for humans.
However, application of $L b$. rhamnosus for fish preservation through controlling the fish-borne spoilage bacteria and their spoilage indices is scarce. Therefore, the present study was undertaken to study the antagonistic efficacy of $L b$. rhamnosus against, specific spoilage bacteria such as $S$. putrefaciens and $P$. flourescens present in the food. They are typically present in very low numbers with their spoilage indices and other native spoilage bacteria in chunks of seabass fish (Lates calcarifer), which is one of the candidate species in the brackishwater aquaculture practices in India.

\section{Materials and Methods}

Bacterial strain, $L b$. rhamnosus was procured from the American Type Culture Collection Centre (ATCC 53103) and revitalized in MRS agar (Deman Rogosa Sharpe-Hi-Media, India, Deman et al., 1960) medium at $37^{\circ} \mathrm{C}$ for $24 \mathrm{hrs}$ aerobically. $L b$. rhamnosus cells $(1.0 \mathrm{ml})$ were inoculated into $10 \mathrm{ml}$ MRS broth and shaker incubated at $37^{\circ} \mathrm{C}, 150 \mathrm{rpm}$ for $24 \mathrm{hrs}$. Five $\mathrm{ml}$ of this inoculum was transferred into $25 \mathrm{ml}$ MRS broth and shaker incubated at $37^{\circ} \mathrm{C}, 150 \mathrm{rpm}$ for $24 \mathrm{hrs}$ (Polak-Berecka et al., 2010). Later, Lb. rhamnosus cells were harvested by refrigerated centrifuge (Sorval RC5B @ $47432 \mathrm{~g} / 45 \mathrm{~min} / 5^{\circ} \mathrm{C}$ ). Further, cells were washed in normal saline $(0.85 \% \mathrm{NaCl}(\mathrm{w} / \mathrm{v})$ thrice and quantified as $10^{6} \mathrm{cfu} \mathrm{ml}^{-1}$ by total plate counting.

Isolation of specific spoilage bacteria (SSB) : Specific spoilage bacteria Were isolated by taking $10 \mathrm{~g}$ of partially putrefied seabass meat and homogenized with $90 \mathrm{ml}$ normal saline $(0.85 \% \mathrm{NaCl})$. One $\mathrm{ml}$ of this suspension was inoculated into $25 \mathrm{ml}$ of Brain Heart Infusion Broth (BHI broth) and shaker incubated at $25^{\circ} \mathrm{C} / 24 \mathrm{hrs}(150 \mathrm{rpm})$. One $\mathrm{ml}$ of $\mathrm{BHI}$ inoculum was serially diluted in normal saline and transferred into petri plates with replications. Iron agar was transferred into the petri plates and incubated at $37^{\circ} \mathrm{C} / 24 \mathrm{hrs}$ for the growth of $P$. fluorescens and at $25^{\circ} \mathrm{C} / 24 \mathrm{hrs}$ for $S$. putrefaciens. The composition of medium was as follows: $20 \mathrm{~g}$ peptone:, $3.0 \mathrm{~g}$ meat extract:, $3.0 \mathrm{~g}$ yeast extract:, $0.3 \mathrm{~g}$ ferric citrate:, $0.3 \mathrm{~g}$ sodium thiosulphate:, $5.0 \mathrm{~g}$ sodium chloride:, $0.6 \mathrm{~g}$ L-cysteine:, $15.0 \mathrm{~g}$ agar:, $\mathrm{pH}: 7.40 \pm 0.2$. For S. putrefaciens, after the agar was solidified, iron agar $(2 \mathrm{~mm}$ level) was over laid to create anaerobic condition. This step is important to minimize the possibility of oxidation of the ferrous sulphate which would cause instability of black precipitate). After incubation, S. putrefaciens, appeared as black colonies, whereas $P$. fluorescens as white. Iron agar contains two sources of sulphur, i.e., thiosulphate and L-Cysteine. Bacteria that are able to produce hydrogen sulphide from either sulphur source appeared as black colonies due to precipitation of ferrous sulphide in the agar. Non-hydrogen sulphide producing bacteria appeared as white colonies (Shewan et al., 1960). The isolates of $S$. putrefaciens and $P$. fluorescens were maintained in $\mathrm{BHI}$ broth $(\mathrm{Hi}-$ Media, India) containing $20 \%$ glycerol at $-80^{\circ} \mathrm{C}$. Successive specific spoilage bacterial cultures were inoculated into $\mathrm{BHI}$ broth and revitalized before the experiments. 
Confirmation of specific spoilage bacteria : S.putrefaciens and $P$. fluorescens were characterized using tests such as Gramreaction $(\mathrm{KOH})$, shape and motility (Phase contrast Microscopy), cytochrome oxidase, catalase formation $\left(\mathrm{H}_{2} \mathrm{O}_{2}, 3 \% \mathrm{v} / \mathrm{v}\right)$, glucose metabolism (O/F test), reduction of TMAO-TMA, $\mathrm{H}_{2} \mathrm{~S}$ production (Gram et al., 1987), production of DNAase, decarboxlyase and ornithine (Shewan et al., 1960). Specific spoilage bacteria such as S. putrefaciens ATCC 8071 and P. fluorescens ATCC 1352 were procured from the American Culture Type Collection (ATCC) and their cultural characteristics were compared with the specific spoilage bacterial isolates (Stenstrom and Molin, 1990) used in this study.

Deferred antagonism assay : Production of antimicrobial substances from $L b$. rhamnosus was detected by "Deferred antagonism assay" (Barefoot and Klaenhammer, 1983). Cells of Lb. rhamnosus (Producer strain) were harvested then washed with sterile distilled water. Twenty $\mu$ l of these cells $\left( \pm 10^{7} \mathrm{cfu} \mathrm{m}^{-1}\right)$ were spotted on the surface of MRS agar plates and incubated for

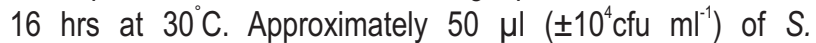
putrefaciens and $P$. flurorescens were inoculated separately into $8.0 \mathrm{ml}$ of $\mathrm{BHI}$ soft agar ( $0.8 \%)$, after uniform mixing, this was over laid on the plates without disturbing the producer strain. After incubation at $30^{\circ} \mathrm{C} / 24 \mathrm{hrs}$, the spot from producer strain was examined for zone of inhibition against the indicator bacteria. Inhibition was recorded positive if the width of clear zones around the colonies of the producer strain was greater than $2.0 \mathrm{~mm}$.

Production of antimicrobial substances from $L b$. rhamnosus : In order to evaluate the production of antimicrobial substances, $25 \mathrm{ml}$ of the spent culture from $L b$. rhamnosus was treated with $40 \%$ ammonium sulphate $(\mathrm{w} / \mathrm{v})$ and allowed to remain at $4{ }^{\circ} \mathrm{C} / 30$ $\mathrm{min}$. This filtrate was then centrifuged and passed through 0.42 $\mu \mathrm{m}$ pore-size filters. Half of each filtrate was neutralized with $5 \mathrm{M}$ $\mathrm{NaOH}$ (pH 6.8) and evaporated through vacuum to $5.0 \mathrm{ml}$. The resultant filtrate was subjected to heat treatments at $100^{\circ} \mathrm{C}$ and $121^{\circ} \mathrm{C}$ for $10 \mathrm{~min}$, respectively, (Silva et al., 1987) and tested for antagonism against specific spoilage bacteria.

Agar-well diffusion assay : Spent culture of $L b$. rhamnosus was assayed for antagonism through Agar-well diffusion assay (Tagg et al., 1971) specific spoilage bacteria. (50 $\mu$ l of $10^{4} \mathrm{cfu} \mathrm{m}^{-1}$ of a log-phase) like $S$. putrefaciens and $P$. fluorescens were transferred separately into sterile petri plates. Iron agar was dispensed into the petri plate. Wells of $7.0 \mathrm{~mm}$ diameter was made into the plate and then sealed using $15 \mu \mathrm{l}$ of $(0.8 \%)$ soft agar. The concentrated and heat inactivated spent culture of two fold dilution $(200 \mu \mathrm{l})$ was transferred into the well. The plates were then allowed to remain at room temperature for $30 \mathrm{~min}$ and then incubated at $37^{\circ} \mathrm{C} / 24 \mathrm{hrs}$. The zone of inhibition were measured excluding the wells.

Associate growth of Lactobacillus rhamosus against $S$. putrefaciens and $P$. fluorescens : $S$. putrefaciens, $P$. flourescens and Lactobacillus rhamnosus were separately subcultured in $\mathrm{BHI}$ and MRS broths, respectively, and incubated at $30^{\circ} \mathrm{C} / 12 \mathrm{hrs}$ on a shaker incubator (100 rpm). SSB were then inoculated $(1.0 \mathrm{ml})$ separately into $100 \mathrm{ml}$ of $\mathrm{BHI}$ broth to provide an initial cell density of approximately $10^{3} \mathrm{cfu} \mathrm{\textrm {ml } ^ { - 1 }}$. The initial level of $L b$. rhamnosus cells inoculated $(3.0 \mathrm{ml})$ into $\mathrm{BHI}$ broth was approximately $10^{7} \mathrm{cfu} \mathrm{ml}^{-1}$. The flasks were incubated at $30^{\circ} \mathrm{C} / 12$ $\mathrm{hr}$ in shaker incubator (100 rpm). All the experiments were repeated thrice. One $\mathrm{ml}$ of inoculum from the co-culture broth was drawn every day for estimation of bacterial cell density. The cell counts were assessed by spread plating using $1.0 \mathrm{ml}$ aliquots, serially diluted and plated on iron agar and MRS agar plates. The plates were incubated for $24 \mathrm{hr} / 30^{\circ} \mathrm{C}$ and colonies were counted and expressed as cfu $\mathrm{ml}^{-1}$.

Preparation of seabass fish meat chunks : Fresh seabass fish fillets of $40 \mathrm{~g}$ were cut into chunks ( $4.0 \mathrm{~cm}$ thickness) and taken into the petri plates. Scores of $0.5 \mathrm{~cm}$ deep were made on four places of each chunks using sterile blade. Lb. rhamnosus cells, $5.0 \mathrm{ml}\left(10^{7} \mathrm{cfu} \mathrm{ml}^{-1}\right)$ were coated on the chunks using micro pipette. The plates were sealed externally using parafilm to avoid cross contamination and incubated at $37^{\circ} \mathrm{C} / 2$ days (Kannappan et al., 2004).

Estimation of native fish spoilage bacteria with spoilage indices : Proteolytic and lipolytic bacteria, total plate counts, coliforms, E.coli, mesophilic and thermophilic spore forming bacteria were determined over a period of 3 days susing media such as Milk agar, Tributryn agar, Plate count agar, VRBA, (Violet Red bile agar) EMB (Eosin Methylene blue) agar, etc. (Hi-Media, India). All these bacteria were re-confirmed through various biochemical tests (Stenstrom and Molin, 1990). For estimating the changes in fish spoilage indices, $L b$. rhamnosus cells were coated on seabass fish meat chunks as described above. However, the chunks were allowed to remain with the cell suspension for 2 days. TMA-N, TVB-N and $\mathrm{pH}$ were estimated for 2 days. The changes of TMA-N and TVB-N were determined through Conway micro diffusion method (AOAC, 1980). Uncoated chunks of $L b$. rhamnosus were considered as control. The $\mathrm{pH}$ was measured using a combination electrode attached to a pH meter (Electronic Corporation of India) in the fish meat after estimating the native spoilage bacteria and $L b$. rhamnosus.

Statistical analysis : All the tests were repeated thrice; average and standard deviations were calculated. Repeated measures of ANOVA were followed to evaluate the effect of bacterial inhibition and reduction of amines between the control and $L b$. rhamnosus cells coated on fish chunks.

\section{Results and Discussion}

Total length of seabass fish was $54 \pm 0.2 \mathrm{~cm}$, total width: $14 \pm 0.2 \mathrm{~cm}$, weight of whole fish: $1.8 \pm 0.2 \mathrm{~kg}$. Total plate count (TPC) level was $8 \times 10^{5} \mathrm{cfu} \mathrm{g}^{-1}$, specific spoilage bacteria was 
$20 \times 10^{3} \mathrm{cfu} \mathrm{g}^{-1}$, proteolytic bacteria $20 \times 10^{4} \mathrm{cfu} \mathrm{g}^{-1}$, lipolytic bacteria were $15 \times 10^{3} \mathrm{cfu} \mathrm{g}^{-1}$, whereas mesophilic spore formers $4 \times 10^{2} \mathrm{cfu}$ $\mathrm{g}^{-1}$, coliforms $20 \times 10^{3} \mathrm{cfu}^{-1}$ and thermophilic spore formers were $2 \times 10^{1} \mathrm{cfu} \mathrm{g}^{-1}$, respectively. All these values would vary in accordance with the size, feeding habits, migration and sex of fish. However, the values are agreeable as compared with other seabass fish (Kocatepe and Turan, 2012). In agar spot method, the highest inhibitory zone (Table 1) was observed against $S$. putrefaciens $(20 \mathrm{~mm})$ followed by $P$. fluroescens $(18 \mathrm{~mm})$.

Spent culture of $L b$. rhamnosus inhibited the growth of Bacillus brevis, B. pumilus, B. subtilis, Escherichia coli, Pseudomonas aeruginosa, Staphylococcus aureus, Vibrio harveyi, Acinetobacter sp. and Arthrobacter sp. (Sarika et al., 2010). Usually majority of LAB may not inhibit Gram-negative bacteria, if so it gives narrow inhibition. Much data was not available to directly support antagonism against $S$. putrefaciens and $P$. fluroescens. But the spent culture of $L b$. rhamnosus treated at $100^{\circ} \mathrm{C}$ showed highest zone of inhibition against $S$. putrefaciens $(28 \mathrm{~mm})$, whereas spent culture of $L b$. rhamnosus, treated at $121^{\circ} \mathrm{C}$ showed lesser zone of inhibition against $P$. fluorescens $(25.0 \mathrm{~mm})$ and $S$. putrefaciens $(23.0 \mathrm{~mm})$, respectively. The culture filtrate and extracellular protein concentrate of $L b$. rhamnosus possessed antimicrobial substances which were active against $P$. aeruginosa, E. coli, Enterobacter aerogenes, S. aureus, Salmonella sp., Helicobacter pylori, Campylobacter jejuni, Bacillus cereus, B. megaterium and L. monocytogenes (Ambalam et al., 2009). The spent culture of Lb. rhamnosus has proved to contribute antioxidant, whitening, moisture-retention properties in cosmetic applications (Tsai et al., 2013). Lb. rhamnosus strains exhibit antimicrobial activity against food spoilage bacteria, gastrointestinal pathogens, as well as Candida and Aspergillus sp. (Pithva et al., 2014).

Here, the zone of inhibition was moderately higher throughout the treatment at $100^{\circ} \mathrm{C}$. Lb. rhamnosus cells were controlled Edward siellatarda infection and the cumulative mortality caused by E. tarda in Tilapia (Oreochromis niloticus) fish (Pirarat et al., 2006). Therefore, it was evident that the concentrated filtrate (spent culture) of $L b$. rhamnosus will be considerably more effective at $100^{\circ} \mathrm{C}$ than at $121^{\circ} \mathrm{C}$ in significant level. Although, the inhibitory mechanism of spent culture was not characterized in this study. However, the source of antimicrobial activity cannot be attributed to the acidity of spent culture, since spent culture was neutralized to $\mathrm{pH} 6.8$.

It was evident that the inhibitory effects might be due to the secondary metabolites such as organic acids, hydrogen peroxide and bacteriocins etc., produced by LAB. Nisin obtained from $L A B$ such Lactococcus lactis has been commonly accepted as bacterial inhibitor (GRAS status) in milk that also inhibits various fish-borne bacteria (Kannappan et al., 2004). Consequently, the spent culture of $L b$. rhamnosus can be effectively used against fish spoilage bacteria. During co-culture, Lb. rhamnosus showed inhibition of $S$. putrefaciens on $2^{\text {nd }}$ day by $2.40 \log _{10}$ difference as compare to control whereas $P$. fluorescens got inhibited on the $2^{\text {nd }}$ day by $2.28 \log _{10}$ difference (Table 2).

Table 1: Antagonism of $L b$. rhamnosus cells and its heat activated spent culture against $S$. putrefaciens and $P$. fluorescens at $37^{\circ} \mathrm{C}$

\begin{tabular}{lll}
\hline Producer strain & Indicator bacteria & Zone of inhibition \\
\hline Cells of $L$ b. rhamnosus & S. putrefaciens & $20.0 \pm 0.2$ \\
Cells of $L$ b. rhamnosus & P. fluorescens & $18.0 \pm 0.2$ \\
Spent culture of $(200 \mu l) L b$. rhamnosus $(7.0 \mathrm{pH})$ sterilized at $121^{\circ} \mathrm{C}$ & S. putrefaciens & $23.0 \pm 0.5$ \\
Spent culture of $(200 \mu l) L$. rhamnosus $(7.0 \mathrm{pH})$ sterilized at $121^{\circ} \mathrm{C}$ & P. fluorescens & $25.0 \pm 0.5$ \\
Spent culture $(200 \mu \mathrm{l})$ of $L$ b. rhamnosus $(7.0 \mathrm{pH})$ sterilized at $100^{\circ} \mathrm{C}$ & S. putrefaciens & $28.0 \pm 1.0$ \\
Spent culture $(200 \mu \mathrm{l})$ of $L$ b. rhamnosus $(7.0 \mathrm{pH})$ sterilized at $100^{\circ} \mathrm{C}$ & P. fluorescens & $29.0 \pm 0.5$ \\
\hline
\end{tabular}

Values are mean of three replicate $\pm S D$

Table 2 : Antagonism of $L b$. rhamnosus cells against the growth of $S$. putrefaciens and $P$. fluorescens in $B H I$ broth through co-culture at $37^{\circ} \mathrm{C}$ for three days

\begin{tabular}{lllllllll}
\hline $\begin{array}{l}\text { Storage } \\
\text { period } \\
\text { in days }\end{array}$ & $\begin{array}{l}\text { Lactobacillus } \\
\text { rhamnosus }\end{array}$ & $\mathrm{pH}$ & $\begin{array}{l}S . \\
\text { fluorescens }\end{array}$ & $\begin{array}{l}P . \\
\text { putrefaciens }\end{array}$ & $\begin{array}{l}S . \\
\text { putrefaciens }\end{array}$ & $\mathrm{pH}$ & $\begin{array}{l}P . \\
\text { fluorescens }\end{array}$ & $\mathrm{pH}$ \\
\hline Initial & $5.90 \pm 0.2$ & $7.30 \pm 0.3$ & $2.00 \pm 0.0$ & $2.00 \pm 0.0$ & $2.00 \pm 0.0$ & $7.20 \pm 0.3$ & $2.00 \pm 0.0$ & $7.20 \pm 0.3$ \\
I & $7.04 \pm 0.1$ & $7.00 \pm 0.2$ & $2.47 \pm 0.1$ & $2.47 \pm 0.1$ & $4.90 \pm 0.2$ & $7.80 \pm 0.2$ & $4.75 \pm 0.2$ & $8.10 \pm 0.3$ \\
II & $6.82 \pm 0.2$ & $5.80 \pm 0.2$ & ND & ND & $3.00 \pm 0.1$ & $8.10 \pm 0.3$ & $3.00 \pm 0.1$ & $8.40 \pm 0.2$ \\
III & $4.60 \pm 0.1$ & $5.60 \pm 0.1$ & ND & ND & $2.50 \pm 0.1$ & $8.20 \pm 0.3$ & $2.30 \pm 0.1$ & $8.50 \pm 0.1$ \\
\hline
\end{tabular}

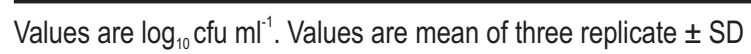


Lb. rhamnosus was able to inhibit 2.40 log load of both bacteria grew in $\mathrm{BHI}$ broth. Lb. rhamnosus, grew in increasing and decreasing trends (4.6 log loads) on $3^{\text {rd }}$ day. Considerable level of S. putrefaciens and $P$. fluoresences survived at $5.6 \mathrm{pH}$. The $\mathrm{pH}$ was significantly reduced to 5.6 with $L b$. rhamnosus. But, in control the $\mathrm{pH}$ increased to 8.50. In general, $L b$. rhamnosus cells have strong efficacy to antagonize Aeromonas salmonicida in rain bow trout fish which cause Furunculosis disease (Nikoskelainen et al., 2001). Repeated measures of ANOVA showed that inhibition of $S$. putrefaciens and $P$. fluorescens was significantly different from control $\left(F_{14}=23290.7, P<0.001\right)$. There was a significant difference between the storage days in inhibition of $S$. putrefaciens $\left(F_{3,12}=400.21, P<0.001\right)$. But there was no significant difference between the control and co-culture of $L b$. rhamnosus with $P$. fluoresences $\left(F_{1,4} 4.62, P=0.09\right)$. The storage days did not vary significantly in inhibiting $P$. fluorescens. $\left(F_{3,12}=\right.$ $1.41, P=0.28)$. Lb. rhamnosus cell coat inhibited $E$. coli on $3^{\text {rd }}$ day of storage by 2.0 log differences as compared to control. This case was also same with specific spoilage bacteria.

Proteolytic bacteria was inhibited by $L b$. rhamnosus on $3^{\text {rd }}$ day of storage by 1.30 log difference (Table 3 ). It has been proved that Lb. rhamnosus and its spent culture inhibited foodborne bacteria such as $V$. parahaemolyticus, $E$. coli, $B$. cereus and S. aureus (Leela et al., 2005). Lb. rhamnosus did not inhibit LLB, however there might have been inhibition if the storage period was extended further. Lb. rhamnosus inhibited MSF on $3^{\text {rd }}$ day of storage by 1.0 log difference as compared to control. $L b$. rhamnosus also inhibited TSF on the $2^{\text {nd }}$ day of storage by $0.50 \mathrm{log}$ difference. Lb. rhamnosus cells coating on fish chunks inhibited E. coli (Susanna et al., 2000) and the overall coliform load reached to $2.0 \mathrm{log}$ in the fish. In control, the coliforms load attained $2.90 \mathrm{log}$. Lb. rhamnosus cells with spent culture, inhibited human pathogenic bacteria such as enterotoxigenic $E$. coli, entero pathogenic E.coli, Klebsiella pneumoniae, Shigella flexneri, Salmonella typhimurium, Enterobacter cloacae, Pseudomonas aeruginosa, Enterococcus faecalis and Clostridium difficile through in-vitro experiments (Forestier et al., 2001).

In the present study also proteolytic bacteria such as $P$ seudomonas species was inhibited by $L b$. rhamnosus. Sarika et al., (2010) reported that $L b$. rhamnosus spent culture inhibited various spoilage bacteria. Further, research is needed to elucidate the possible muscle protein changes on fish by coating Lb. rhamnosus. Repeated measures of ANOVA showed that there was significant difference among the various group of bacteria inhibited by $L b$. rhamnosus $\left(\mathrm{F}_{5,12}=322.868, \mathrm{P}=<0.01\right)$.

Table 3 : Effect of coating $L b$. rhamnosus cells against growth changes in various fish borne spoilage bacterial cells in seabass fish chunks for three days at $37^{\circ} \mathrm{C}$

\begin{tabular}{|c|c|c|c|c|c|c|c|c|c|c|}
\hline $\begin{array}{l}\text { Storage } \\
\text { period } \\
\text { in days }\end{array}$ & TPC & Coli & E. coli & SSB & PLB & LLB & $\begin{array}{l}\text { Lb. } \\
\text { rhamnosus }\end{array}$ & MSF & TSF & $\mathrm{pH}$ \\
\hline \multicolumn{11}{|c|}{ Seabass fish chunks coated without $L b$. rhamnosus (control) } \\
\hline Initial day & $4.69 \pm 0.2$ & $4.69 \pm 0.2$ & $4.00 \pm 0.1$ & $4.00 \pm 0.1$ & $3.77 \pm 0.1$ & $3.69 \pm 0.1$ & ND & $3.30 \pm 0.1$ & $1.00 \pm 0.0$ & $6.70 \pm 0.3$ \\
\hline I & $5.77 \pm 0.2$ & $5.00 \pm 0.2$ & $5.90 \pm 0.1$ & $5.36 \pm 0.1$ & $4.90 \pm 0.2$ & $4.84 \pm 0.2$ & & $4.60 \pm 0.2$ & $1.47 \pm 0.0$ & $7.60 \pm 0.3$ \\
\hline ॥ & $4.39 \pm 0.1$ & $4.90 \pm 0.2$ & $4.00 \pm 0.1$ & $4.00 \pm 0.1$ & $3.90 \pm 0.0$ & $3.54 \pm 0.1$ & & $3.00 \pm 0.1$ & $1.00 \pm 0.0$ & $8.70 \pm 0.4$ \\
\hline \multicolumn{11}{|c|}{ Seabass fish chunks coated with $L b$. rhamnosus } \\
\hline Initial day & $4.69 \pm 0.1$ & $4.69 \pm 0.2$ & $4.00 \pm 0.1$ & $4.00 \pm 0.1$ & $3.77 \pm 0.1$ & $3.69 \pm 0.1$ & $7.00 \pm 0.3$ & $3.30 \pm 0.1$ & $1.00 \pm 0.0$ & $6.60 \pm 0.2$ \\
\hline I & $4.17 \pm 0.1$ & $2.47 \pm 0.1$ & $2.00 \pm 0.0$ & $2.47 \pm 0.1$ & $2.60 \pm 0.1$ & $3.39 \pm 0.0$ & $8.00 \pm 0.2$ & $2.00 \pm 0.0$ & ND & $6.00 \pm 0.1$ \\
\hline II & $3.69 \pm 0.1$ & $2.00 \pm 0.0$ & ND & ND & ND & $3.00 \pm 0.1$ & $6.00 \pm 0.1$ & ND & ND & $5.90 \pm 0.2$ \\
\hline
\end{tabular}

Values are mean of three replicate $\pm S D$ and are expressed in $\log _{10} c f u m l^{-1}, T P C$ - total plate count, coli-coliforms, PLB - proteolytic bacteria, LLB lipolytic bacteria, MSF - Mesophilic spore formers, TSF - thermophilic spore formers, ND : Not detected

Table 4 : Changes in seabass fish quality indices against coating $L b$. rhamnosus cells

\begin{tabular}{llllllll}
\hline $\begin{array}{l}\text { Storage } \\
\text { period } \\
\text { in days }\end{array}$ & $\begin{array}{l}\text { Growth } \\
\text { of } L b . \\
\text { rhamnosus } \\
\text { (log) }\end{array}$ & $\begin{array}{l}\text { TMA-N } \\
\mathrm{mg} \%\end{array}$ & $\begin{array}{l}\text { TVB-N } \\
\mathrm{mg} \%\end{array}$ & $\mathrm{pH}$ & $\begin{array}{l}\text { TMA-N } \\
\mathrm{mg} \% \\
\text { as control }\end{array}$ & $\begin{array}{l}\text { TVB-N } \\
\mathrm{mg} \% \\
\text { as control }\end{array}$ & $\begin{array}{l}\mathrm{pH} \\
\text { Control }\end{array}$ \\
\hline Initial & 8.50 & $80 \pm 1.0$ & $70 \pm 0.5$ & $6.8 \pm 0.2$ & $160 \pm 0.8$ & $120 \pm 0.9$ & $6.8 \pm 0.1$ \\
I & 9.50 & $75 \pm 0.5$ & $65 \pm 0.9$ & $6.0 \pm 0.1$ & $170 \pm 0.8$ & $110 \pm 0.8$ & $7.8 \pm 0.2$ \\
II & 8.00 & $70 \pm 1.0$ & $60 \pm 0.7$ & $5.7 \pm 0.2$ & $110 \pm 0.9$ & $105 \pm 0.8$ & $8.4 \pm 0.1$ \\
\hline
\end{tabular}

Values are mean of three replicate \pm SD, TMA-N: Trimethylamine nitrogen, TVB-N: Total volatile base nitrogen 
The bacterial inhibition was also significantly different between storage days $\left(F_{2,24}=1165.46, P<=0.01\right)$. Pairwise comparison among various groups of bacteria showed that the effect of inhibition on $E$. coli, Proteolytic bacteria, specific spoilage bacteria, were similar. Rest of them were significantly different from one another. Normally, TMA-O was known to react with the fish fats and produce the typical spoilage odor (Anthony et al., 1990). In the present study, it was found that $10^{3}$ to $10^{4} \mathrm{cfu} \mathrm{g}^{-1}$ of $S$. putrefaciens was required for producing $160 \mathrm{mg} \mathrm{g}^{-1}$ of TMA-N in control. TMA-N, 10 to $15 \mathrm{mg}$ for $100 \mathrm{~g}$ of fish is usually regarded a limit beyond which the fish would be considered slightly (Table 4) spoiled (Saito et al., 1959). In control TVB-N values changed from 120 to $105 \mathrm{mg} \%$, whereas TMAO-N was $160-110 \mathrm{mg} \%$. Therefore, it was obvious that $L b$. rhamnosus cells were able to reduce TMA-N to $95 \mathrm{mg} \%$ as compared to control, where as TVB-N was 45 to $50 \mathrm{mg} \%$ respectively. The use of Lactobacillus plantarum and Lactobacillus pentosus cells prevented the formation of total volatile nitrogen contents such as TVA and TMA in vacuum packed fish Dicentrarchus labrax (Bassi et al., 2009).

The rate of reduction was higher in case of TMA-N as compared to TVB-N. However, higher level of NPN in control showed more multiplication of bacteria that would produce amines. The reduction of TMA-N and TVB-N might be due to the antagonism excerted by $L b$. rhamnosus cells or their bacteriocin like inhibitory substances against amines producing specific spoilage bacteria present in the fish. Lactic acid bacteria such as Lb. helveticus, Lactococcus lactis and Pediococcus acidilactici proved to be the best probiotic bacteria for reducing TMA-N and TVB-N in fresh Mackerel fish chunks (Kannappan and Manja, 2011). Lb. rhamnosus incorporated probiotic diet has facilitated growth and enzyme change in L. vannamei (Kumar etal., 2013).

Kannappan and Manja (2011) documented that coating of various lactic acid bacterial cells such as Lb. helveticus, Lactococcus lactis and Pediococcus acidilactici were able to reduce TMA-N and TVB-N in fresh mackerel fish meat. As per repeated measures ANOVA, there was a significant difference between TMA-N in the treated sample and control $\left(F_{1,4}=5716.6\right.$, $P<0.001)$. There was also significant difference between the storage days on the reduction of TMA-N $\left(F_{2,8}=351.16, P<0.001\right)$ and TVB-N in the treated fish and control $\left(\mathrm{F}_{1,4}=691.7, \mathrm{P}<0.001\right)$. There was also significant difference between the storage days on the reduction of TVB-N $\left(F_{2.8}=203.5, P<0.001\right)$. TMA-N reduction in fish would reduce the characteristic fishy odor. Coating of cells of LAB such as Carnobacterium and Lactobacillus plantarum species reduced the fishy smell on Salmon fish caused by amines (Francoise et al., 1996).

The present study suggests that probiotic $L b$. rhamnosus bacteria inhibited most of the spoilage bacteria in fish chunks. This step would also control the formation of amines by controlling spoilage bacteria and preserve fish.

\section{Acknowledgment}

The authors thank the Director, Central Institute of Brackishwater Aquaculture (ICAR-CIBA), Chennai India for providing all the facilities to carry out this research work.

\section{References}

Aberoumand, A. : A review on Pseudomonas in marine fish. World J. fish Marine Sci., 2, 291-296 (2010).

Ambalam, P.S., J.B. Prajapati, J.M. Dave, B.M. Nair, A. Ljungh and B.R.M. Vyas: Isolation and characterization of antimicrobial proteins produced by a potential probiotic strain of human $L b$. rhamnosus 231 and its effect on selected human pathogens and food spoilage organisms. Microbial Ecol. Helth. Ith Dis., 21,211-220 (2009).

Anthony, U.,T. Borresen and C. Christophersen: Is TMA-O a reliable indicator for the marine origin of fishes? Compen. Biochem. Physiol., 97B, 569-571 (1990).

AOAC, Association of Official Analytical Chemists: Official Methods of Analysis. $13^{\text {th }}$ Edn; Washington, DC, (1980).

Balcazer, L.J., I. Blas, I. Ruiz-Zarzuela, D. Cuuningham, D. Vendrel and L.J. Muzquiz: The role of probiotics in aquaculture. Vet. Microbiol., $114,173-186$ (2006).

Barefoot, S.F. and T.R. Klaenhammer: Detection and activity of lacticin B, has bacteriocin produced by Lactobacillus acidophilus. Appl. Environ. Microbiol.,45, 1808-1815(1983).

Bassi, L.E.,H. Mnasser, N. Shinzato and T. Matsui : Biopreservation of refrigerated and vacuum packed fish Dicentrarchus labrax by lactic acid bacteria. J.Food Sci.,74, 335-340 (2009).

Deman, J.C., M. Rogosa and M.E. Sharpe: Amedium for the cultivation of lactobacilli. J. Appl. Bacteriol., 23, 130-135(1960).

Forestier, C., C. De Champs,C. Vatoux and B. Joly: Probiotic activities of Lb. casei rhamnosus: In vitro adherence to intestinal cells and antimicrobial properties. Res. Microbiol.,152, 167-173 (2001).

Francoise, L., A. Nathalie, J.J. Jean and C. Frederique: Effect of inoculation with lactic acid bacteria in extending the shelf life of vacuum packed cold salmon. Int. J. Food. Sci. Technol.,31, 497 504 (1996).

Ghaly, A.E., D. Dave, S. Budge and M.S. Brooks: Fish spoilage mechanisms and preservation techniques. Rev. Am. J.Appl. Sci., 7, 846-864 (2010).

Gram, L.,G. Trolle and H.H. Huss: Detection of specific spoilage bacteria from fresh fish stored at low at $0^{\circ} \mathrm{C}$ and $20^{\circ} \mathrm{C}$. J. Food Microbiol.,4, 65-72(1987).

Kabir, S.M.L.: Effect of probiotics on broiler meat quality. Afr. J. Biotechnol., 8, 3623-3627 (2009).

Kannappan, S., R.K. Leela and J. Anna: Inhibitory pattern of seafoodborne bacteria in Mackerel fish against nisapline. J. Food Sci. Technol., 41, 105-108 (2004).

Kannappan, S. and K.S. Manja: Efficacy of lactic acid bacteria in the reduction of trimethylamine nitrogen-and related spoilage derivatives of fresh Indian Mackerel fish chunks. Afr. J. Biotechnol.,10, 42-47 (2011).

Kannappan, S. and K.S. Manja: Repressive efficacy of lactic acid bacteria against the human pathogenic and fish-borne spoilage microbiota of fresh Mackerel fish chunks. Afr. J .Biotechnol.,11, 15695-1570 (2012).

Kocatepe, D. and H. Turan: Chemical composition of cultured seabass 
(Dicentrarchus labrax Linnaeus 1758). J. Food Nutr. Res.,51, 3339 (2012).

Kumar, P.N., S.A. Jyothsna, M.H. Reddy and S. Sreevani: Effect of Bacillus subtilis and Lactobacillus rhamnosus incorporated probiotic diet on growth pattern and enzymes in Penaeus vannamei. Int. J. Life Sci. Pharma. Res., 3, 6-11 (2013).

Lara-Flores, M.: The use of probiotics in aquaculture: an overview. Int. Res.J.Microbiol.,2, 471-478(2011).

Leela, R.K., S. Kannappan, R.K. Shantha, K.S. Manja, Mallesha, M. Radhika and H.S. Vasudish Murali: Bacterial profile of dehydrated foods, spice mixtures and their inhibitory pattern by fish-borne Pediococcus cerevisiae and Lactobacillus GG ATCC 53013. J. Food Sci. Technol., 42, 517-520 (2005).

Magdalena, P.B., W. Adam and K. Daniel: Comparison of different methods for detection of antimicrobial activity of probiotic strains of Lactobacillus rhamnosus against some food spoilage microorganisms. Annales UMCS, Biologia, 64, 15-24 (2009).

Ngamkala, S., K. Futami, M. Maita and T. Katagiri: Immunological effects of glucan and Lactobacillus rhamnosus GG, a probiotic bacterium on Nile Tilapia, Oreochromis niloticus intestine with oral Aeromonas changes. Fish. Sci., 76, 833-840 (2010).

Nikoskelainen, S., A.C. Ouwehaud, S. Salminen and G. Bylund: Protection of rainbow trout (Oncorhunchus mykiss) from furunculosis by Lactobacillus rhamnosus. Aquaculture, 198, 229 236 (2001).

Pirarat, N.,T. Kobayashi, T. Katagiri, M. Maita and M. Endo: Protective effects and mechanisms of a probiotic bacterium Lactobacillus rhamnosus against experimental Edwardsiella tarda infection in tilapia (Oreochromis niloticus). Vet. Immunol. Immunopathol.,113, 339-347 (2006).

Pithva, S., S. Shekh, J. Dave, B. Rajiv and M. Vyas: Probiotic attributes of Autochthonous, Lactobacillus rhamnosus strains of human origin. Appl. Biochem. Biotechnol.,173, 259-277 (2014).

Polak-Berecka, M.A. Wasko, M. Kordowska-Wiater, M. Podlesny, Z. Targonski and A. Kubik-Komar: Optimization of medium composition for enhancing growth of Lactobacillus rhamnosus using response surface methodology. Polish. J. Microbiol.,59, 113 $-118(2010)$.

Patil, P.K., M. Muralidhar, H.G. Solanki, P.P. Patel, K. Patel and C. Gopal: Effect of culture intensity and probiotics application on microbiological and environmental parameters in Litopenaeus vannamei culture ponds. J. Environ., Biol, 37, 21-29 (2016).

Saito, T., K. Arai and M. Matsuyoshi: A new method for estimating freshness of fish. Bull. Japa. Soc. Sci. Fish., 24, 749-750 (1959).

Sarika, A.R., A.P. Lipton and M.S. Aishwarya: Bacteriocin production by a new isolate Lactobacillus rhamnosus GPI under different culture conditions. Advance J. Food Sci Technol., 2, 291-297 (2010).

Shewan, J.M., G. Hobbs and W.A. Hodgkiss: Determinative scheme for the identification of certain genera of Gram negative bacteria with special reference to Pseudomonadaceae. J. Appl. Bacteriol., 23, $379-390$ (1960).

Silva, M., N.V. Jacobus,C. Deneke and S.L. Gorbach: Antimicrobial substance from a human Lactobacillus strain. Antimicro. Agents Chemothera., 31, 1231-1233(1987).

Stenstrom, M. and G. Molin: Classification of the spoilage flora of fish with special reference to S. putrefaciens. J. Appl. Bacteriol., 68, 601 $618(1990)$.

Susanna, E., V. Maarit, H. Sebastian, P. Esko, P. Eero and M.S. Tiina: Survival of $E$. coli $0157: \mathrm{H} 7$ in dry sausage fermented by probiotic lactic acid bacteria. J. Sci. Food Agri., 80,2101-2104 (2000).

Tagg, J.R. and A.R. McGiven: Assay system for bacteriocins. J. Appl. Microbiol., 21, 943 (1971).

Tsai, M.S., H.L. You, Y.F. Tang and J.W. Liu: Shewanella soft tissue infection: Case report and literature review. Int. J. Infect. Dis.,12, e119-e124 (2008).

Tsai, C.C., C.F. Chan, W.Y. Huang, J.S. Lin, P. Chan, H.Y. Liu and Y.S. Lin: Applications of Lactobacillus rhamnosus spent culture supernatant in cosmetic ant oxidation, whitening and moisture retention applications. Molecules, 18, 14161-14171 (2013).

Zaheer, A., W. Yanping,C. Qiaoling and M. Imran: Lactobacillus acidophilus bacteriocin from production to their application: An overview. Afr. J. Biotechnol., 9, 2843-2850(2010). 